\title{
The Effect of Non Performing Loan and Capital Adequacy Ratio on Return on Assets in Bank Victoria International, Tbk Period 2009-2018
}

\author{
Waluyo Jati \\ Pamulang University, Banten, Indonesia \\ dosen00565@unpam.ac.id
}

\begin{abstract}
This study aims to determine the effect of Non-Performing Loans and Capital Adequacy Ratio on Return on Assets at PT. Bank Victoria International, Tbk. 2009-2018 period The method used is explanatory research. The analysis technique uses statistical analysis with regression testing, correlation, determination, and hypothesis testing. The results of this study that Non Performing Loans have a significant effect on Return on Assets by $60.4 \%$, hypothesis testing is obtained t count $>t$ table or (3.496> 2.306). Capital Adequacy Ratio has a significant effect on Return on Assets of 2.8\%, hypothesis testing obtained $t$ count $<t$ table or (0.477 <2.306). Non-Performing Loan and Capital Adequacy Ratio simultaneously have a significant effect on Return on Assets, the regression equation is $Y=8.666+0.569 X 1+0.049 X 2$ and a determination value of $60.8 \%$, hypothesis testing is obtained by the value of $F$ count $>F$ table or $(5,431>4,350)$.
\end{abstract}

Keywords

non performing loan; capital adequacy ratio, retum on asset

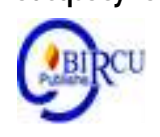

\section{Introduction}

PT Bank Victoria International Tbk (Bank Victoria) as a private commercial bank has operational activities by developing its main mission of consistently providing the best quality service to customers while still observing the principle of prudence. In line with efforts to continuously improve its risk and financial management, Bank Victoria continues to move aggressively in developing professional human resources, has high loyalty to the company, develops information technology and office networks, and is principled and dedicated by supporting the development of personal capabilities supported by the application of the principles of GCG (Good Corporate Governance).

In 1999, Bank Victoria listed its shares on the Jakarta \& Surabaya Stock Exchanges. Since then, Bank Victoria has been active in carrying out various corporate actions, such as a limited public offering and issuing bonds. As of June 2016, the Bank has 103 operational office networks consisting of 1 head office, 7 branch offices, 63 sub-branch offices, and 32 cash offices spread across the Jakarta, Depok, Tangerang, and Bekasi areas.

Supported by reliable human resources, Bank Victoria continues to expand its business through a variety of integrated financial services. PT Bank Victoria International Tbk. (Bank Victoria) has the vision to become the bank of choice for customers who are trusted, healthy, and efficient. The translation of this vision: Customer Choice is that Bank Victoria is known, trusted, and is the choice of customers to meet customer needs for banking products and services. Trustworthy is that Bank Victoria is committed to being a bank that can provide a sense of security and certainty for its customers, employees, 
shareholders, and other stakeholders. Sound and Efficient means that Bank Victoria has a strong capital structure, sound financial conditions, and is supported by efficient banking operations.

Having a Customer Mission is to continually strive to meet customer needs, foster good relationships with customers, and provide the best service to customers. People in developing professional, principled, and dedicated human resources to provide services and meet customer needs. Operation is carrying out banking operations by applying the prudential principle efficiently and sustainably. Risk Management is conducting risk and financial management prudently and consistently and always applying the principles of Good Corporate Governance.

A bank is an intermediary institution for parties with excess funds and parties who lack funds. Where a bank has several functions, one of which is an agent of trust. Agent of trust means that in its business activities a bank relies on public trust. The community believes that their money will not be misused by the bank, the money will be managed properly and the bank will not go bankrupt (Sigit Triandaru and Totok Budisantoso, 2008: 9).

To maintain public trust, banks must maintain their financial performance. Bank financial performance can be assessed from several indicators. One of the main indicators used as the basis for the assessment is the financial statements of the bank concerned. Based on the financial statements, some financial ratios can be calculated that are commonly used as the basis for assessing the soundness of a bank. Financial ratios are the results of calculations between two kinds of bank financial data, which are used to explain the relationship between the two financial data which is generally expressed numerically, either in percentage or times. (Slamet Riyadi, 2006: 155).

Profitability in the banking world can be calculated by using Return on Assets (ROA). In this case, Return On Asset (ROA) is the ratio between profit before tax to total assets. ROA is important for banks because ROA is used to measure the effectiveness of a company in generating profits by utilizing its assets. According to Bank Indonesia regulations, the best standard for Return On Assets in terms of Indonesian banks is at least $1.5 \%$. The greater the ROA of a bank, the greater the level of profit achieved by the bank and the better the position of the bank in terms of asset use. (Lukman Dendawijaya, (2010: 120).

The fluctuating ROA value is influenced by several other factors. Where these factors can also be used in assessing the performance and profit obtained by a bank, such as CAR (representing capital), NPL (representing credit risk). CAR (Capital Adequacy Ratio) is the ratio of the minimum capital adequacy ratio (KPMM). NPL is a financial ratio that is used as a proxy for the rate of return on credit given by depositors to a bank, in other words, NPL is the level of bad credit at the bank. This ratio shows that the ability of bank management to manage non-performing loans is provided by the bank. The smaller the Non-Performing Loan (NPL), the smaller the credit risk borne by the bank. The number of non-performing loans (NPL) has increased which is a burden on the income of PT. Bank Victoria International Tbk. Meanwhile, the Capital (CAR) of PT. Bank Victoria International Tbk in recent years has experienced fluctuations so that it has not been optimal in generating profitability (ROA). And the ROA value at PT. Bank Victoria International Tbk has also decreased every year, the decreased ROA value occurs due to the influence of increased bad credit, as well as fluctuating capital.

Based on the existing background, the researcher felt the need to research with the title "The Effect of Non-Performing Loans (NPL) and Capital Adequacy Ratio (CAR) on Return On Assets (ROA) at PT. Bank Victoria International Tbk Period 2009-2018" 


\section{Review of Literatures}

\subsection{Non Performing Loan}

Some actions that can be taken in credit supervision are by conducting credit restructuring, rescheduling, considering new loans, and liquidating collateral.

\subsection{Capital Adequacy Rasio}

The ratio that shows the extent to which all bank assets that contain credit risk, investments, securities, claims on other banks) are also financed from the bank's capital funds in addition to obtaining funds from sources outside the bank, such as funds from the public, loans, and others.

\subsection{Return on Aset}

Return On Assets (ROA) shows the company's ability to use all its assets to generate profit after tax. According to Hery in Angelia and Toni (2020) profitability is the ratio used to measure a company's ability to generate profits with the company's resources. Companies that have stability in obtaining profits can give signals to the public about the ability to pay dividends.

\section{Research Methods}

The population in this study is based on financial reports for 10 years of PT. Bank Victoria International, Tbk. The sampling technique in this research is a saturated sample, where all members of the population are sampled. Thus the sample in this study was financial statements for 10 years. The type of research used is associative, where the aim is to find out how to find the relationship between the independent variables and the dependent variable. In analyzing the data, the classical assumption test, regression, correlation coefficient, determination coefficient, and hypothesis test were used, either partially or simultaneously.

\section{Results and Discussion}

\subsection{Descriptive Analysis}

This test is used to determine the minimum and maximum percentage, average percentage, and standard deviation of each variable. The results are as follows: Descriptive Statistics Analysis Results Table

Table 1. Descriptive Statistics

\begin{tabular}{lr|r|r|r|r} 
& $\mathrm{N}$ & Minimum & Maximum & Mean & Std. Deviation \\
\hline Non Performing Loan $(\mathrm{X} 1)$ & 10 & 1.8 & 4.6 & 3.252 & .9093 \\
\hline Capital Adequacy Ratio $(\mathrm{X} 2)$ & 10 & 16.8 & 18.8 & 17.816 & .8307 \\
\hline Return on Asset $(\mathrm{Y})$ & 10 & 1.9 & 3.8 & 2.730 & .6504 \\
\hline Valid N (listwise) & 10 & & & & \\
\hline
\end{tabular}

Non-performing loans obtained a minimum value of $1.8 \%$ and a maximum value of $4.6 \%$ with an average of $3.25 \%$ with a standard deviation of $0.90 \%$.

The Capital Adequacy Ratio obtained a minimum value of $16.8 \%$ and a maximum value of $18.8 \%$ with an average value of $17.8 \%$ with a standard deviation of $0.83 \%$.

Return on Asset obtained a minimum value of $1.9 \%$ and a maximum value of $3.8 \%$ with an average of $2.73 \%$ with a standard deviation of $0.65 \%$. 


\subsection{Verification Analysis}

This analysis aims to determine the effect of the independent variable on the dependent variable. The test results are as follows:

\section{a. Multiple Linear Regression Analysis}

This regression test is intended to determine changes in the dependent variable if the independent variable changes. The test results are as follows:

Table 2. Multiple Liner Regression Test Results

\section{Coefficients $^{\mathrm{a}}$}

Unstandardized

Coefficients

Standardized

Coefficients

\begin{tabular}{|c|c|c|c|c|c|c|}
\hline \multicolumn{2}{|c|}{ Model } & $\mathrm{B}$ & Std. Error & Beta & $\mathrm{t}$ & Sig. \\
\hline 1 & (Constant) & 8.666 & 3.657 & & .000 & 1.00 \\
\hline & Non Performing Loan (X1) & .569 & .177 & .796 & 3.220 & .015 \\
\hline & Capital Adequacy Ratio (X2) & .049 & .193 & .063 & .255 & .806 \\
\hline
\end{tabular}

a. Dependent Variable: Return on Asset (Y)

Based on the test results in the table above, the regression equation $\mathrm{Y}=8.666+$ $0.569 \mathrm{X} 1+0.049 \mathrm{X} 2$ is obtained. From this equation it is explained as follows:

1) A constant of 8.666 means that if the Non-Performing Loan and the Capital Adequacy Ratio do not exist, then there is a Return on Assets value of 8.666 points.

2) The non-performing loan regression coefficient is 0.569 , this number is positive, meaning that every time there is an increase in Non-Performing Loans of 0.569 , the Return on Assets will also increase by 0.569 points.

3) The regression coefficient of the Capital Adequacy Ratio is 0.049, this number is positive, meaning that every time there is an increase in the Capital Adequacy Ratio of 0.049, the Return on Assets will also increase by 0.049 points.

\section{b. Correlation Coefficient Analysis}

Correlation coefficient analysis is intended to determine the level of strength of the relationship between the independent variable and the dependent variable either partially or simultaneously. The test results are as follows:

Table 3. Testing Results of the Correlation Coefficient of Non Performing Loans on

\section{Return on Assets}

\section{Correlations $^{\mathrm{b}}$}

Non Performing Return on Asset

\begin{tabular}{llrrr} 
& & Loan $(\mathrm{X} 1)$ & \multicolumn{1}{c}{ (Y) } \\
\hline Non Performing Loan $(\mathrm{X} 1)$ & Pearson Correlation & 1 & $.777^{* * *}$ \\
\cline { 2 - 4 } & Sig. (2-tailed) & & .008 \\
\hline Return on Asset $(\mathrm{Y})$ & Pearson Correlation & $.777^{* *}$ & 1 \\
\cline { 2 - 4 } & Sig. (2-tailed) & .008 & \\
\hline
\end{tabular}

Based on the test results obtained a correlation value of 0.777 means that NonPerforming Loans have a strong relationship to Return on Assets. 
Table 4. Test Results Correlation Coefficient Capital Adequacy Ratio against Return on Assets

Correlations $^{\mathrm{b}}$

Capital

Adequacy Ratio Return on Asset

\begin{tabular}{llrr} 
& & (X2) & (Y) \\
\hline Capital Adequacy Ratio & Pearson Correlation & 1 & -.166 \\
\cline { 2 - 4 }$(\mathrm{X} 2)$ & Sig. (2-tailed) & & .646 \\
\hline Return on Asset $(\mathrm{Y})$ & Pearson Correlation & -.166 & 1 \\
\cline { 2 - 4 } & Sig. (2-tailed) & .646 & \\
\hline
\end{tabular}

Based on the test results obtained a correlation value of -0.166 means that the Capital Adequacy Ratio has a low negative relationship to Return on Assets.

Table 5. Testing Results of Non-Performing Loan Correlation Coefficient and Capital Adequacy Ratio simultaneously to Return on Assets

\section{Model Summary}

\begin{tabular}{l|c|cc|c} 
Model & R & R Square & $\begin{array}{c}\text { Adjusted R } \\
\text { Square }\end{array}$ & \multicolumn{2}{c}{$\begin{array}{c}\text { Std. Error of the } \\
\text { Estimate }\end{array}$} \\
\hline 1 & $.780^{\mathrm{a}}$ & .608 & .496 & .4617 \\
\hline a. Predictors: (Constant), Capital Adequacy Ratio (X2), Non Performing Loan (X1)
\end{tabular}

Based on the test results obtained a correlation value of 0.780 means that the Non Performing Loan and the Capital Adequacy Ratio simultaneously have a strong relationship to Return on Assets.

\section{c. Analysis of the Coefficient of Determination}

The analysis of the coefficient of determination is intended to determine the percentage of influence of the independent variable on the dependent variable, either partially or simultaneously. The test results are as follows:

Table 6. Results of Testing the Coefficient of Determination of Non-Performing Loans on Return on Assets

\section{Model Summary}

\begin{tabular}{|c|c|c|c|c|}
\hline Model & $\mathrm{R}$ & R Square & $\begin{array}{l}\text { Adjusted R } \\
\text { Square }\end{array}$ & $\begin{array}{l}\text { Std. Error of the } \\
\text { Estimate }\end{array}$ \\
\hline & $.777^{\mathrm{a}}$ & .60 & .5 & .433 \\
\hline
\end{tabular}

a. Predictors: (Constant), Non Performing Loan (X1)

Based on the test results, it is found that the determination value is 0.604 , which means that the Non-Performing Loan has an effect of $60.4 \%$ on Return on Assets.

Table 7. Test Results of Capital Adequacy Ratio Determination Coefficient against Return on Assets

\section{Model Summary}

\begin{tabular}{l|c|cr|r} 
Model & $\mathrm{R}$ & R Square & $\begin{array}{c}\text { Adjusted R } \\
\text { Square }\end{array}$ & $\begin{array}{c}\text { Std. Error of the } \\
\text { Estimate }\end{array}$ \\
\hline 1 & $.166^{\mathrm{a}}$ & .028 & -.094 & .6802 \\
\hline a. Predictors: (Constant), Capital Adequacy Ratio (X2) & &
\end{tabular}


Based on the test results, the determination value is 0.028 , which means that the Capital Adequacy Ratio has an influence contribution of $2.8 \%$ to Return on Assets.

Table 8. The Results of Testing the Coefficient of Determination of Non Performing Loans and Capital Adequacy Ratio to Return on Assets

\section{Model Summary}

\begin{tabular}{l|c|c|cr} 
Model & $\mathrm{R}$ & R Square & $\begin{array}{c}\text { Adjusted R } \\
\text { Square }\end{array}$ & $\begin{array}{c}\text { Std. Error of the } \\
\text { Estimate }\end{array}$ \\
\hline 1 & $.780^{\mathrm{a}}$ & .608 & .496 & .4617 \\
\hline a. Predictors: (Constant), Capital Adequacy Ratio (X2), Non Performing Loan (X1)
\end{tabular}

Based on the test results, the determination value is 0.608 , which means that the Non-Performing Loan and the Capital Adequacy Ratio simultaneously have an influence contribution of $60.8 \%$ on Return on Assets, while the remaining $39.2 \%$ is influenced by other factors.

\section{d. Hypothesis Testing}

\section{Partial hypothesis test (t-test)}

Hypothesis testing with the t-test is used to determine which partial hypothesis is accepted.

Table 9. Hypothesis Test Results for Non Performing Loans on Return on Assets

\section{Coefficients $^{\mathrm{a}}$}

Unstandardized

Coefficients

\begin{tabular}{l|c|c|c|c|c} 
Model & B & Std. Error & Beta & t & Sig. \\
\hline 1 (Constant) & .922 & .535 & & 1.722 & .123 \\
\hline Non Performing Loan $(\mathrm{X} 1)$ & .556 & .159 & .777 & 3.496 & .008 \\
\hline
\end{tabular}

Standardized

Coefficients

a. Dependent Variable: Return on Asset (Y)

Based on the test results in the table above, the value of $t$ count $>t$ table or (3.496>2.306) is obtained, thus there is a significant influence between Non Performing Loans on Return on Assets.

Table 10. Hypothesis Test Results of Capital Adequacy Ratio to Return on Assets Coefficients $^{\text {a }}$

Unstandardized Standardized

Coefficients Coefficients

\begin{tabular}{llr|rrrr} 
Model & $\mathrm{B}$ & Std. Error & \multicolumn{1}{c}{ Beta } & \multicolumn{1}{c}{$\mathrm{t}$} & \multicolumn{1}{c}{ Sig. } \\
\hline 1 & (Constant) & 5.051 & 4.867 & & 1.038 & .330 \\
\cline { 2 - 8 } & Capital Adequacy Ratio $(\mathrm{X} 2)$ & -.130 & .273 & -.166 & -.477 & .646 \\
\hline
\end{tabular}

a. Dependent Variable: Return on Asset (Y)

Based on the test results in the table above, the $t$ value $<t$ table or $(-0.477<2.306)$ is obtained, thus there is a negative but insignificant effect between the Capital Adequacy Ratio on Return on Assets.

\section{Simultaneous Hypothesis Test (Test F)}

Hypothesis testing with the $\mathrm{F}$ test is used to determine which simultaneous hypothesis is accepted. 
Table 11. Hypothesis Test Results for Non-Performing Loans and Capital Adequacy Ratio to Return on Assets

ANOVA $^{\mathrm{a}}$

\begin{tabular}{llr|rrr|r|r} 
Model & & Sum of Squares & df & Mean Square & F & Sig. \\
\hline 1 & Regression & 2.315 & 2 & 1.158 & 5.431 & $.038^{\mathrm{b}}$ \\
\cline { 2 - 7 } & Residual & 1.492 & 7 & .213 & & \\
\cline { 2 - 7 } & Total & 3.807 & 9 & & & \\
\hline
\end{tabular}

Based on the test results in the table above, the calculated $\mathrm{F}$ value $>\mathrm{F}$ table or $(5,431>4,350)$, thus there is a significant effect between Non Performing Loans and Capital Adequacy Ratio on Return on Assets.

\subsection{The Effect of Non Performing Loans on Return on Assets}

Non-Performing Loans have a significant effect on Return on Assets with a correlation of 0.777 or have a strong relationship with an influential contribution of $60.4 \%$. Hypothesis testing obtained $t$ value $>t$ table or (3.496>2.306). Thus, there is a significant influence between Non Performing Loans on Return on Assets.

\subsection{The Effect of Capital Adequacy Ratio on Return on Assets}

Capital Adequacy Ratio has a significant effect on Return on Assets with a correlation of -0.166 or has a low negative relationship with an influential contribution of $2.8 \%$. Hypothesis testing obtained $t$ value $<\mathrm{t}$ table or $(-0.477<2.306)$. Thus, there is a negative but insignificant influence between the Capital Adequacy Ratio and Return on Assets.

\subsection{Effect of Non Performing Loans and Capital Adequacy Ratio on Return on Assets}

Non-Performing Loans and Capital Adequacy Ratio have a significant effect on Return on Assets by obtaining the regression equation $\mathrm{Y}=8.666+0.569 \mathrm{X} 1+0.049 \mathrm{X} 2$, the correlation value is 0.780 or has a strong relationship with an influential contribution of $60.8 \%$ while the remaining $39.2 \%$ influenced by other factors. Hypothesis testing obtained the value of $F$ count $>F$ table or $(5,431>4,350)$. Thus, there is a significant influence between Non-Performing Loans and Capital Adequacy Ratio on Return on Assets

\section{Conclusion}

Non Performing Loans have a significant effect on Return on Assets with a contribution of $60.4 \%$ influence. Hypothesis test obtained $t$ value $>t$ table or $(3.496>$ 2.306).

Capital Adequacy Ratio has a significant effect on Return on Assets with an influence contribution of $2.8 \%$. Hypothesis test obtained $t$ value $<t$ table or $(-0.477<$ 2.306).

Non Performing Loans and Capital Adequacy Ratio have a significant effect on Return on Assets with a contribution of $60.8 \%$ influence while the remaining $39.2 \%$ is influenced by other factors. Hypothesis testing obtained the value of $\mathrm{F}$ count $>\mathrm{F}$ table or $(5,431>4,350)$. 


\section{Suggestions}

Based on the results of the research and these conclusions, the researchers provide the following suggestions:

1. To monitor the growth rate or movement of Non-Performing Loans (NPLs) so as not to violate the provisions of Indonesian banks, it is better if PT. Bank Victoria International Tbk must be more careful in providing credit to prospective customers, first PT. Bank Victoria International Tbk must see the ability of prospective customers to repay their loans.

2. To maintain the level of bank capital (CAR), it is better if PT. Bank Victoria International Tbk pays more attention to the amount of capital owned by a company because capital is the most important factor that a bank must-have. To anticipate the development of the credit or loan expansion business scale.

3. For researchers who will conduct further research and use financial ratios, it is recommended to further analyze the relationship and influence between the ratios by adding the independent variables studied and adding to the period in the financial reporting year that the research will be carried out.

\section{References}

Angelia, N., and Toni N. (The Analysis of Factors Affecting Dividend Policy in Food and Beverage Sector Manufacturing Companies Listed in Indonesia Stock Exchange in 2015-2017. Budapest International Research and Critics Institute-Journal (BIRCIJournal). P. 902-910.

Agus Harjito \& Martono, (2010) "Financial Management" Yogyakarta: Econisia Publishers.

Agus Sartono. (2010). "Financial Management Theory and Applications", fourth edition, Yogyakarta: BPFE Publisher.

Algifari. (2015). "Regression Analysis for Business and Economics". Yogyakarta: BPFE.

Anjayani, NS., Lutfi, AM., Suhartono, A., Sari, WI., Sunarsi, D. (2020). The Effect of Inventory Turnover and Asset Turnover Ratio to Return on Investment at PT Gudang Garam Tbk. TIN: Applied Informatics Nusantara. Vol. Issue 4 Pages 171-176

Arikunto, Suharsimi (2014). "Research Procedure, A Practice Approach". Jakarta: Rineka Cipta.

Bambang Riyanto, (2011). "Company Spending Basics". The fourth edition, BPFE Yogyakarta. Seventh Printing, Publisher: Ekonesia. Yogyakarta.

Defri. 2012. "The Influence of Capital Adequacy Ratio (CAR), Liquidity and Operational Efficiency on the Profitability of Banking Companies Listed on the IDX." Journal of Management Vol 1, No 1

Dendawijaya. Lukman. 2010, "Banking Management", Jakarta: Ghalia.

Destiana Kamilah Sari. 2016, "The Effect of Capital Adequacy Ratio (CAR), Loan To Deposit Ratio (LDR), Against Return on Assets (ROA), At PT. Bank Central Asia Tbk Period 2008-2016", Pamulang University, South Tangerang.

Fahmi, Irham (2012), "Introduction to Financial Management" First printing. Bandung: Alfabeta Publisher.

Ghozali, Imam. 2005 "Application of Multivariate Analysis with the SPSS Program" Semarang: Diponegoro University Research Agency.

Grafindo Persada.

Harahap Sofyan Syafri, 2008, "Crisis analysis of financial reports", PT. Raja Grafindo Persada, Jakarta. 
Hasibuan, Malayu S.P 2008, "Introduction to Banking Science". Jakarta: Erlangga.

Herlina, Cutt. 2011, "Introduction to Management Science", Jakarta: Yudistira.

Himaniar Triasdini. 2010, "The Effect of CAR, NPL, and ROA on Distribution

Imam Ghozali (2017). "Multivariate Analysis Application with SPSS Program". Fifth Edition. Semarang: Undip Publishing Agency.

Istijanto (2014) "Human Resources Research". Jakarta: PT. Gramedia Pustaka

Physical, J. (2018). The Influence of Financial Performance on Stock Prices (Analysis of

Go Public Property and Real Estate Companies on the Indonesian Stock Exchange. Indonesian Journal of Accountancy, 12 (2).

Physical, J. (2019). The Effect of Liquidity and Working Capital Turnover on Profitability at PT. Sumber Cipta Multiniaga, South Jakarta. PINISI Discretion Review, 3 (1), 29 38.

K Nufus, H Supratikta, A Muchtar, D Sunarsi. (2020). Analysis of Financial Performance: Case Study of PT. X Employee Cooperative. Utopía Y Praxis Latinoamericana. Vol. 25. Pages 429-444

Cashmere, (2010). "Introduction to Financial Management", First Edition, Second Edition, Jakarta: Prenada Media Publisher.

Lestari, Maharani Ika, and Toto Sugiharto, 2007, "The Performance of Foreign Exchange Banks and Non-Foreign Exchange Banks and the Factors That Affect Them. PESAT Proceedings (Psychology, Economics, Literature, Architect \& Civil "21-22 August, Vol.2. Faculty of Economics, Gunadarma University.

M. Saladin Fahmy. 2013, "The Effect of CAR, NPF, BOPO and CAR on the Profitability of Islamic Commercial Banks", State Islamic University of Sunan Kalijaga, Yogyakarta

Martono and Agus Harjito. 2008, "Financial Management", First Edition,

Martono and Agus Harjito, (2011). "Financial Management", Jakarta: Ekonisia Publisher.

Muh. Fuad Alamsyah. 2016, "The Effect of Non Performing Loans and Capital Adequacy on Return on Assets (ROA) at State-Owned Banks Going Public on the Indonesia Stock Exchange", Ichsan University, Gorontalo.

Munawir (2010), "Financial Statement Analysis", Fourth Edition, Liberty Publisher, Yogyakarta.

Munawir. 2007. "Banking Financial Management", Jakarta: PT. Exxel

Riyadi Slamet. 2006, "Banking Assets and Liability Management", Jakarta: FE UI Publishing Institute

Riyanto Bambang. 2013, "Financial Management Edition 1", Semarang: Kencana Agung.

Santoso, Singgih (2015). "Mastering Multivariate Statistics". Jakarta: PT Elex Media Komputindo.

Sartono Agus. 2010, "Financial Management Theory and Application (4th ed)" Yogyakarta: BPFE.

Saryono. Jonathan. 2016, "Quantitative and Qualitative research methods", Yogyakarta: Graha Ilmu.

Sawir, (2003). "Financial Performance Analysis and Corporate Financial Planning", Third edition, Jakarta: Publisher PT. Gramedia Pustaka Utama.

Sigit Triandaru and Totok Budisantoso. 2008, "Banks and Other Financial Institutions" Jakarta: Salemba Empat

Sugiyarso, G. and F. Winarni, "Financial Management (Understanding Financial Statements, Management of Assets, Liabilities and Capital and Measurement

Sugiyono (2017), "Administrative Research Methods: equipped with R \& D Methods". Bandung: Alfabeta. 
Sugiyono. 2009, "Quantitative Research Methods, Qualitative and R \& D", Alfabeta, Bandung.

Suhartono, A., Jati, W., \& Sunarsi, D. (2019). The Effect of Earning Per Share and Return On Assets on Stock Prices at PT. Bank Negara Indonesia Tbk 2009-2018 period. Journal of Management, Business, and Organization (JUMBO), 3 (3), 182-194.

Sunarsi, D. (2020). Implications of Digitalization Umkm. Digitalization of MSMEs, 57. books.google.com

Sutrisno. 2005, "Financial Management: Theory, Concepts, and Applications", Publisher: Ekonisia. Yogyakarta.

Toto P. 2010, "Financial Statement Analysis (Theory and Application)", Central Jakarta: PPM.

Veithzal Rivai, 2013, "Banking Management", Jakarta: PT. Raja Grafindo Persada.

Yusni Nuryani, Denok Sunarsi. (2020). The Effect of Current Ratio and Debt to Equity Ratio on Deviding Growth. JASa (Journal of Accounting, Auditing and Accounting Information Systems) Volume 4, Issue 2, Pages 304-312. 